\title{
7: 17111486-17158632
}

National Cancer Institute

\section{Source}

National Cancer Institute. 7: 17111486-17158632. NCI Thesaurus. Code C41671.

Physical location of AHR_Gene 